\title{
Tilfelli mánaðarins
}

\section{Tilfelli}

Sæmundur J. 21 árs gömul heilsuhraust frumbyrja óskaði eftir Oddsson utanbastsdeyfingu (epidural analgesia) vegna deildarlæknir hríðarverkja og var hún pá með 3-4 cm útvíkkun á leghálsi. Vel gekk að koma leggnum fyrir Aðalbjörn í liðbili L3-L4 og náðist góð verkjastilling Porsteinsson með hefðbundinni deyfingu. Engin óvenjuleg svæfinga- og gjörgæslulæknir brottfallseinkenni frá taugakerfi komu fram og lífsmörk héldust óbreytt.
Um 90 mínútum síðar kvartaði konan yfir pyngslatilfinningu hægra megin í andliti og við skoðun sást sigið augnlok peim megin og pröngt sjáaldur (sjá mynd 1).

Hver er sennilegasta greiningin?

Fyrirspurnir og bréfaskipti: Sæmundur J. Oddsson, svæfinga-, giörgæsluog skurðstofusviði Landspítala Hringbraut, 101 Reykjavík.

saemiodds@hotmail.com

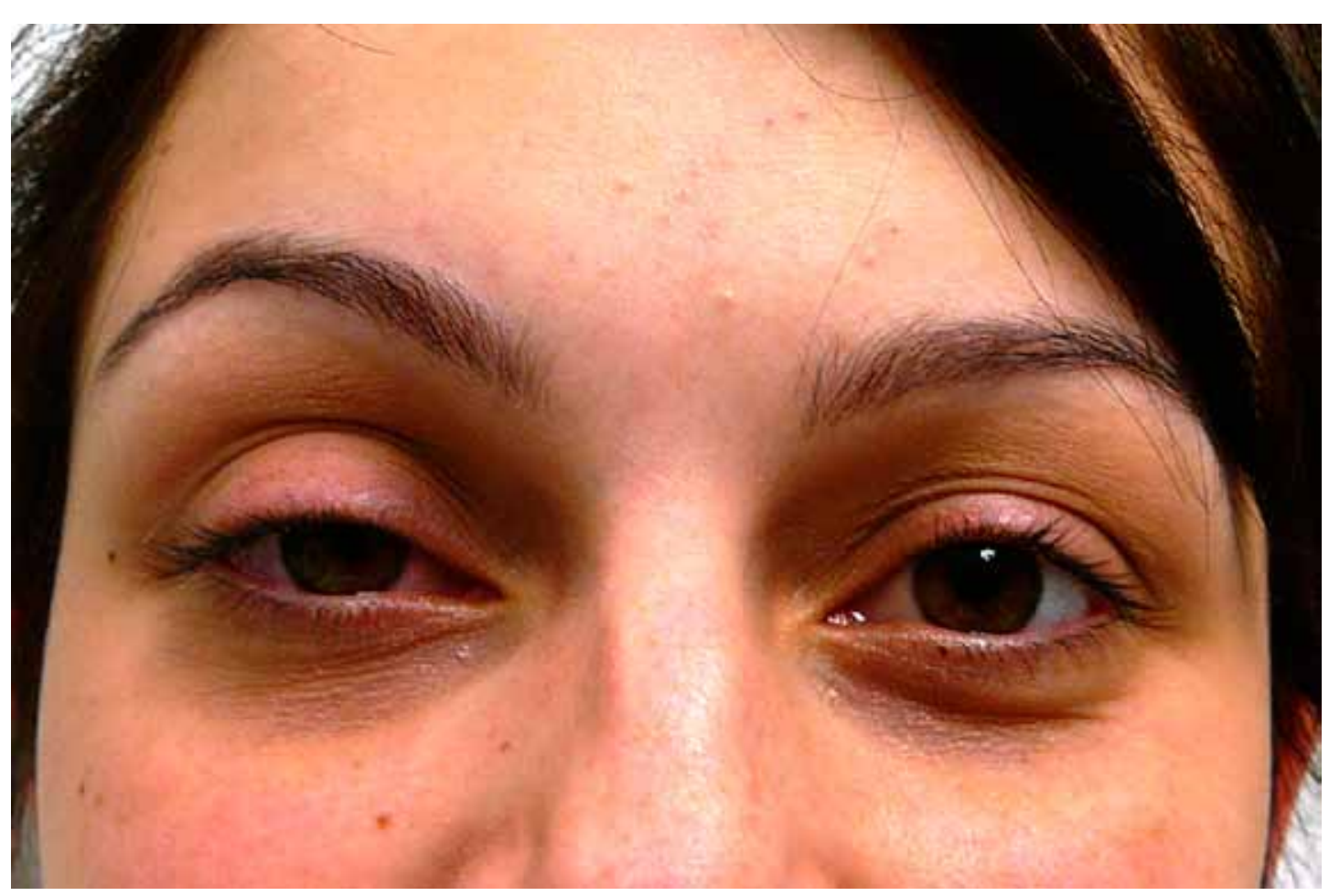




\section{Svar við tilfelli mánaðarins}

Case of the month: Ptosis during labour

Tilfelli mánaðarins: Sigið augnlok í fæðingu

Key words: ptosis, symphathetic innervation, eye, epidural analgesia, complication
Greiningin er Horners heilkenni sem kemur fram pegar semjuítaugun (sympathetic innervation) til auga truflast. Par með verða utansemjuáhrif ríkjandi í og við augað. Einkennin eru pröngt sjáaldur (miosis), sigið augnlok (ptosis) og truflun á starfsemi svitakirtla (anhydrosis).

Í pessu tilfelli komu ofangreind einkenni fram 90 mínútum eftir gjöf á hefðbundnum skammti af deyfingu (Bupivacain (4 ml Marcain ${ }^{\circledR} 2,5 \mathrm{mg}$ / $\mathrm{ml})$, Sufentanil (2 ml Sufenta $\left.{ }^{\circledR} 5 \mathrm{mg} / \mathrm{ml}\right)$ og 4 $\mathrm{ml}$ af $\mathrm{NaCl}$ 0,9\%). Deyfingarleggurinn (Perifix ${ }^{\circledR}-$ Katheter, Braun M) var lagður í liðbil L3-L4. Dýpt frá húð að utanbasti var 4,5 cm og að auki voru 7,5 cm af deyfilegg prætt inn í utanbastsrúmið. Ekki bakkaði blóð eða vökvi í deyfilegginn pegar sogað var með sprautu. Prufuskammtur af deyfingu var gefinn og engin óvænt brottfallseinkenni frá taugakerfi komu fram og lífsmörk héldust óbreytt. Eftir pað var gefinn hefðbundinn skammtur af deyfingu og innan 10 mínútna frá gjöf deyfingar hafði náðst góð verkjastilling og engin óvenjuleg einkenni til staðar.

Eftir að einkenni Horners heilkennis komu fram sýndi nánari skoðun eðlilega meðvitund og að góð deyfing var til staðar. Lega deyfingarleggjar var óbreytt og lífsmörk stöðug. Við taugaskoðun voru hreyfingar og kraftar útlima án athugasemda, hins vegar var vægt minnkað snertiskyn í húð á hægri kinn og á hægra læri. Prófun heilatauga var eðlileg að pví undanskildu að erfitt var að meta aðra heilataug (n. opticus) par sem sjáaldur hægra auga var áberandi prengra en vinstra megin. Auk pess var áberandi meiri roði í augnhvítu hægra auga samanborið við vinstra auga.

Horners heilkenni getur verið vegna truflana miðlægt í taugakerfinu, til dæmis milli undirstúku og C8-T2 hluta mænu, en algengara er að ástæðuna sé að finna í úttaugakerfinu. Á meðal algengustu orsaka eru skemmdir miðlægt í taugakerfi, til dæmis vegna blóðpurrðar í heilastofni eða æxlisvaxtar. Taugaáverkar eru pó pekktari orsök og er heilkennið pekkt við skaða á armflækju (brachial plexus) eða flysjun í vegg hálsslagæða. Að auki er pekkt að æxlisvöxtur í lungnatoppi, svonefnd Pancoast-æxli, geta vaxið inn í taugahnoð og valdið Horners heilkenni. Heilkenninu hefur einnig verið lýst í tengslum við mígreniköst. ${ }^{1}$
Horners heilkenni er sjaldgæf hliðarverkun utanbastsdeyfinga og kemur fram í um 1 af 10.000 tilfellum. $^{2}$ Tíðnin virðist vera hærri á meðal pungaðra kvenna með birtar tíðnitölur um 0,5\% til $4 \%$ en ástæða pessa er ekki að fullu ljós. ${ }^{2,3}$ Ein skýring gæti verið að rúmmál utanbastsbils er minna hjá punguðum konum og útbreiðsla deyfingar pví meiri en annars. Rúmmálið er minna vegna penslu bláæða í bilinu en sú pensla er tilkomin vegna pess að pungað leg prýstir á neðri holbláæð (inferior vena cava) pannig að blóðflæðið leitar inn í „,vertebral“ og "azygos“ kerfið. Að auki er talið að fæðingahríðir geti valdið prýstingsbylgju í utanbastsbilinu sem mögulega pumpa lyfinu upp á við. ${ }^{4}$ Einnig er mögulegt að deyfileggur geti verið staðsettur í hinu örpunna innanbastsbili (subdural space) en pekkt er erlent sjúkratilfelli par sem litlu magni af deyfilyfi var sprautað í pað bil og hlaust af há deyfing. ${ }^{5}$ Önnur möguleg orsök er líffærafræðilegur breytileiki. Semju ítaugun sjáaldurs er yfirleitt talin koma frá taugarótarbilum C8-T1 en sýnt hefur verið fram á að ítaugunin liggur oft neðar og jafnvel í gegnum fleiri en eina taugarót á bilinu C8-T4. ${ }^{6}$

Framvinda fæðingarinnar var pannig að fylgst var náið með sjúklingi og ákveðið að gefa ekki meira af deyfilyfjum í utanbastslegginn. Eftir rúmar tvær klukkustundir voru öll merki um Horners heilkenni horfin og komu engin ný einkenni frá taugakerfi fram. Hjartsláttur barns og lífsmörk móður voru áfram stöðug. Rúmri klukkustund síðar kom heilbrigt barn í heiminn. Móður og barni heilsaðist vel að lokinni fæðingu.

Höfundar pakka Tómasi Guðbjartssyni fyrir yfirlestur og góð ráð.

\section{Heimildir}

1. http://emedicine.medscape.com/article/1220091-overview Desember 2009.

2. Biousse V, Guevara RA, Newman NJ. Transient Horner's syndrome after lumbar epidural anesthesia. Neurology 1998; 51: 1473-5.

3. Sprung J, Haddox JD, Maitra-D'Cruze AM. Horner's syndrome and trigeminal nerve palsy following epidural anaesthesia for obstetrics. Can J Anaesth 1991; 38: 767-71.

4. Bromage PR. Spread of analgesia solutions in the epidural space and their site of action: a statistical study. $\mathrm{Br}$ J Anasth 1962; 34: 161-78.

5. Mohan J, Potter JM. Pupillary constriction and ptosis following caudal epidural analgesia. Anaesthesia 1975; 30: 769-73.

6. Ray BS, Hinsey IC, Geohegan WA. Observations of the distribution of the symphathetic nerves to the pupil as determined by stimulation of the anterior roots in man. Ann Surg 1943; 118: 647-55. 